\title{
Estimation of the Biochemical Parameters in Baby Powdered Milk
}

\section{Lokonuzzaman Ahmmed, Md. Nazrul Islam, M. Saidul Islam, Md. Ruhul Amin, Md. Sher Ali}

Inorganic Research Laboratory, Department of Chemistry, University of Rajshahi, Rajshahi, Bangladesh

\section{Email address:}

lokonuzzaman3@gmail.com (L.Zaman)

\section{To cite this article:}

Lokonuzzaman Ahmmed, Md. Nazrul Islam, M. Saidul Islam, Md. Ruhul Amin, Md. Sher Ali. Estimation of the Biochemical Parameters in Baby Powdered Milk. Science Journal of Chemistry. Vol. 3, No. 4, 2015, pp. 67-71. doi: 10.11648/j.sjc.20150304.11

\begin{abstract}
This paper deals with the study of important biochemical parameters such as protein, lactose and acidity of baby (0-6 months) powdered milk of different brands available in the market. The percentage of protein, lactose and acidity were determined by using biochemical methods.
\end{abstract}

Keywords: Biochemical Parameters, Protein, Lactose, Acidity, Baby Powdered Milk, biochemical methods

\section{Introduction}

Milk is a good source of protein, fat and major minerals and considered as an ideal food for mankind. For infants breast milk is usually the only source of food during first four to six months in their lives. The best way to feed an infant is exclusive breastfeeding for the first six months of life, and breastfeeding alongside complementary foods after 6 months and for as long as the mother wishes to do so[1]. In the absence of breast milk, lactose-based formulations are the source of most nutrients, playing a key role in the development of infants [2]. Different macronutrients (proteins, lipids, and carbohydrates) and micronutrients (vitamin and minerals) have been added to infant formulations to improve their nutritional quality and to cover a range of specific requirements [3] Nevertheless, infant's adaptability is very limited when exposed to either very high or very low amounts of micronutrients [4]. Infant formulas are an imperfect approximation of breast milk and there are inherent differences between breast milk and infant formula [5]. The present study deals with some important biochemical parameters such as percentage of protein, lactose and acidity of the studied milk samples.

\section{Experimental}

\subsection{Analytical Techniques}

In present investigation, Micro Kjeldahl Method [6] was used to carry out the protein analysis. Determination of acidity was carried out by titratable Method [7] and lactose was determined by Volumetric Method [8].

\subsection{Reagents and Chemicals}

All chemicals and reagent used were chemicals and reagents grades. All working solutions were also prepared in redistilled water.

\subsection{Procedure}

\subsubsection{Estimation of Protein}

\section{(i). Digestion Phase}

1) About $0.5 \mathrm{~g}$ of sample was taken on a paper sheet.

2. The paper with sample was carefully inserted into the previously cleaned and dried Kjeldahl flask. About $2 \mathrm{~g}$ of catalyst mixture and $10 \mathrm{~mL}$ of conc. $\mathrm{H} 2 \mathrm{SO} 4$ were added into the flask.

3) Then the sample was digested for $2-3 \mathrm{hrs}$ by heating at $3500 \mathrm{C}-4000 \mathrm{C}$ in the digestion chamber until the color changes from black to light bottle green.

4) It was then cooled under running tap water.

5) $50 \mathrm{~mL}$ distilled water was added carefully and slowly.

\section{(ii). Distillation Phase}

1) $50 \mathrm{~mL}$ boric acid was taken in a $250 \mathrm{~mL}$ conical flask and about 5 drops of mixed indicator solution was added.

2) After cooling the Kjeldahl flask, pinch of pumice stone was taken in the flask to prevent bumping. Then about $33 \mathrm{~mL}$ $40 \%$ sodium hydroxide was added slowly.

3) Kjeldahl flask was adjusted into the distillation unit.

4) Receiving tube was dipped under $4 \%$ boric acid solution previously taken in a conical flask and distilled for about five 
hrs.

5. After complete distillation, ammonia absorbed boric acid was taken and titrated against standard $0.1 \mathrm{~N} \mathrm{HCI} \mathrm{until}$ the color of the indicator pointed at an acidic condition (from blue to brown color)

\section{(iii). Calculation}

The percentage of protein present in the sample was calculated by the following equation $[7,9]$.

$$
\% \text { of Nitrogen }=\frac{0.014 \times \text { Normality of HCI } \times \text { volume of HCI required } \times 100}{\text { Weight of sample }}
$$

$$
\% \text { of Protein }=\% \text { of nitrogen } \times 6.38
$$

The percentages of protein in baby powdered milk of different brands are given in table-1.

\subsubsection{Estimation of Lactose}

Lactose of the milk samples was determined by volumetric method. To estimate the lactose content in powdered milk about $2 \mathrm{~g}$ milk sample was taken in a small beaker and dissolved with $10 \mathrm{~mL}$ warm distilled water. $10 \mathrm{~mL}$ of liquid milk was diluted with distilled water to a volume of $200 \mathrm{~mL}$ and about 8 drops of 10 percents acetic acid solution was added. After the precipitate had settled, it was filtered off and washed with cold water. The filtrate was boiled in a flask and the albumin precipitated. This solution was cooled and filtered again. The precipitate was washed with cold water. The filtrate and washed water were mixed and measured accurately in a measuring cylinder. A portion of the filtrate was placed in a burette and this was run into a boiling mixture of $10 \mathrm{~mL}$ Fehling's solution ( $5 \mathrm{~mL}$ Fehling solution-1 and $5 \mathrm{~mL}$ Fehling solution-2) and $40 \mathrm{~mL}$ water. After the copper had been completely precipitated the number of milliliters used was read. $10 \mathrm{~mL}$ Fehling's solution corresponds to 0.0675 gram milk sugar [10]. The percentages of lactose of baby (0-6 months) powdered milk of different brands are given in table- 2 .

\subsubsection{Estimation of Titratable Acidity}

Distilled water was added to powdered milk in order to dilute them to fluid milk basis before titrating for acidity [9]. About 8-10 g of powdered milk was dissolved in small amount of warmed distilled water and cooled. Then titration was carried out with $\mathrm{NaOH}$ using phenolphthalein indicator.
Titration was carried out with $\mathrm{NaOH}$ using phenolphthalein indicator. Titratabe acidity of powdered milk was measured by the following formula [11].

$$
\% \text { of lactic acid }=\frac{\text { Milliliters } N / 10 \text { alkali } \times 0.009}{\text { Grams of sample }} \times 100
$$

The acidity of baby (0-6 months) powdered milk of different brands are given in table -3 .

\section{Results and Discussion}

Percentage of protein, lactose and acidity of Baby $(0 \sim 6$ months) powdered milk and equivalent milk of same product of different brands available in market are shown in table-1.

Table 1 indicates that the highest percentage of protein is present in Biomil soy (18.50) and the lowest amount is present in Lactogen-1 (15.42). The protein content of each of the milk is given on the packet by the respective company based on the method of production. The percentage of protein of investigated milks exceeds the given value. A significant difference is observed in Biomil soy, Eldorin-1, Lactogen-1 and Mother's smile-1 between experimental and given value. Other brands are found to show small difference. Only Babycare-1 has the closest value. The reason of getting excess protein in all these milks may be due to the presence of non- protein nitrogenous substances such as urea nitrogen, amino nitrogen, creatinine, uric acid, adenine and guanine

\begin{tabular}{|c|c|c|c|c|c|c|c|}
\hline \multirow{2}{*}{$\begin{array}{l}\text { Name of } \\
\text { brand }\end{array}$} & \multirow{2}{*}{$\begin{array}{l}\text { Country of } \\
\text { origin }\end{array}$} & \multirow{2}{*}{$\begin{array}{l}\text { Equivalent milk(g } \\
\text { of powdered } \\
\text { milk/L) }\end{array}$} & \multicolumn{2}{|l|}{ Percentage of protein } & \multicolumn{2}{|l|}{ Percentage of lactose } & \multirow{2}{*}{$\begin{array}{l}\text { Acidity of } \\
\text { powdered milk } \\
(\text { Mean } \pm \text { S .D. }) \\
\end{array}$} \\
\hline & & & $\begin{array}{l}\text { Experimental value } \\
(\text { Mean } \pm \text { S.D.) }\end{array}$ & $\begin{array}{l}\text { Given } \\
\text { value* }\end{array}$ & $\begin{array}{l}\text { Experimental value } \\
(\text { Mean } \pm \text { S.D. })\end{array}$ & Given value* & \\
\hline Biomil-1 & Belgium & 107.69 & $17.73 \pm 0.44$ & 12.5 & $52.83 \pm 0.21$ & 54.0 & $1.09 \pm 0.07$ \\
\hline Lactogen-1 & Switzerland & 109.28 & $15.42 \pm 0.71$ & 10.5 & $56.20 \pm 0.08$ & 55.7 & $0.67 \pm 0.13$ \\
\hline M Smile-1 & Australia & 108.90 & $16.97 \pm 0.32$ & 12.0 & $51.60 \pm 0.22$ & 55.0 & $0.66 \pm 0.08$ \\
\hline Mamilag-1 & Poland & 109.28 & $15.98 \pm 0.42$ & 12.5 & $53.40 \pm 0.00$ & 59.0 & $0.68 \pm 0.08$ \\
\hline Baby care-1 & Korea & 108.30 & $17.74 \pm 0.00$ & 12.9 & $51.02 \pm 0.16$ & 58.2 & $0.71 \pm 0.00$ \\
\hline Biomil soy & Belgium & 111.60 & $18.50 \pm 0.36$ & 12.5 & $61.25 \pm 0.11$ & 60.0 & $1.28 \pm 0.77$ \\
\hline
\end{tabular}
[12].

Table 1. Biochemical composition of baby (0-6months) powdered milk and equivalent milk of different brands.

* Values given in the level of the container/packet 


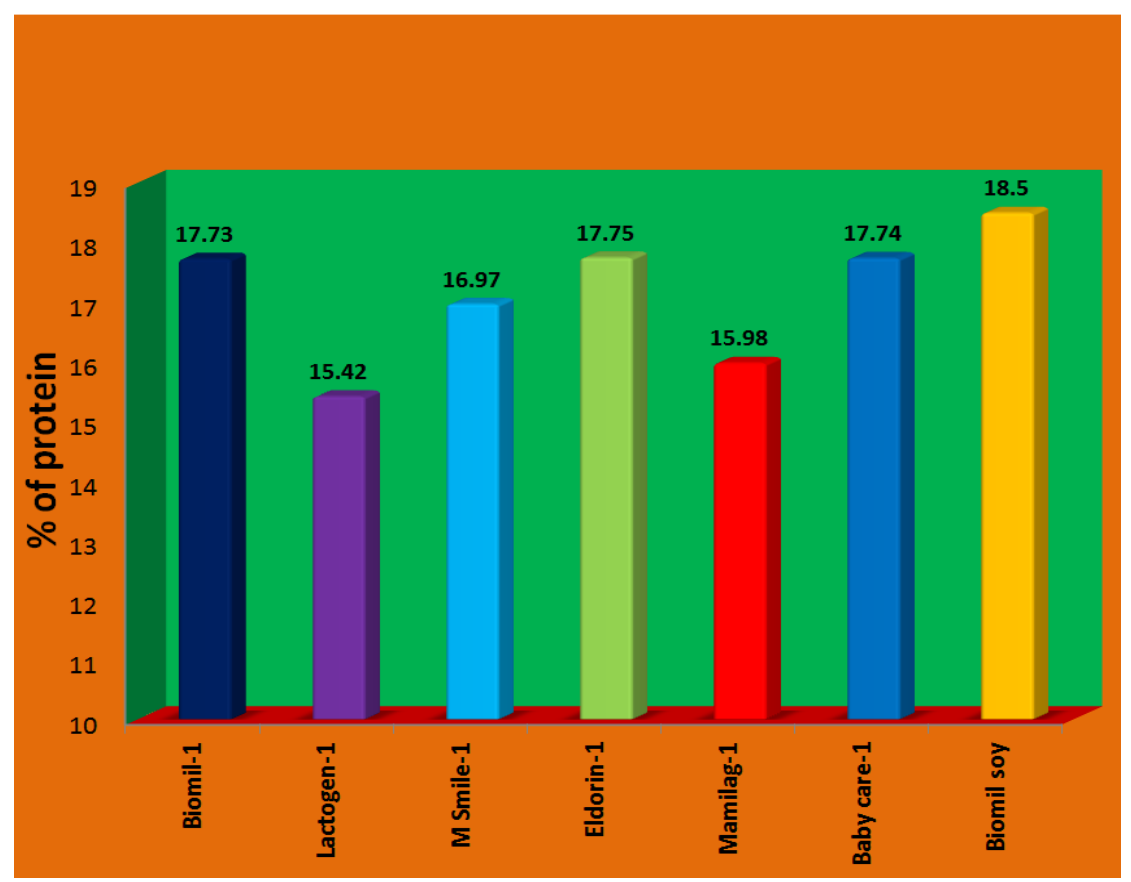

Fig. 1. The variation of percentage of protein in baby (0-6 months) powdered milk of different brands.

According to the American college of sports Medicine, protein should make up 12 to 15 percent of total calories and how many grams per day that should be consumed is based on body weight(in kilograms): infants: 2.2 grams per $\mathrm{kg}$ of body weight. The recommended protein intake for infants from birth to 6 months is about $9.1 \mathrm{~g}$ per day $(1.52 \mathrm{~g}$ per $\mathrm{kg}$ of body weight per day). In 2002, the National Academy of Science (NAS) recommended dietary allowances (RDAs) of protein for infants $0-6$ months of age are 9.1 grams. The protein content in mother milk is $1.1 \mathrm{~g} / 100 \mathrm{ml}$ (Constituents of human milk, United Nations University Centre). In the nutrition edema group the protein level of the breast milk is $1.13 \mathrm{~g} / 100 \mathrm{ml}$ (range 0.5 to $1.8 \mathrm{~g} / 100 \mathrm{ml}$ ) [13].

The percentage of lactose in milk samples varies from $51.02 \%$ to $62.49 \%$. The lactose is found in Lactogen-1, Eldorin-1 and Biomil soy exceeds their given value. Among these, Eldorin-1 contains the highest amount of lactose $(62.49 \%)$ and Baby care-1 contains the lowest amount of lactose (51.02 \%). Biomil-1 and Lactogen-1 shows negligible difference between experimental and given values. But Mother's smile-1, Mamilag-1 and Baby care-1 contain comparatively lesser amount of lactose than their given value.

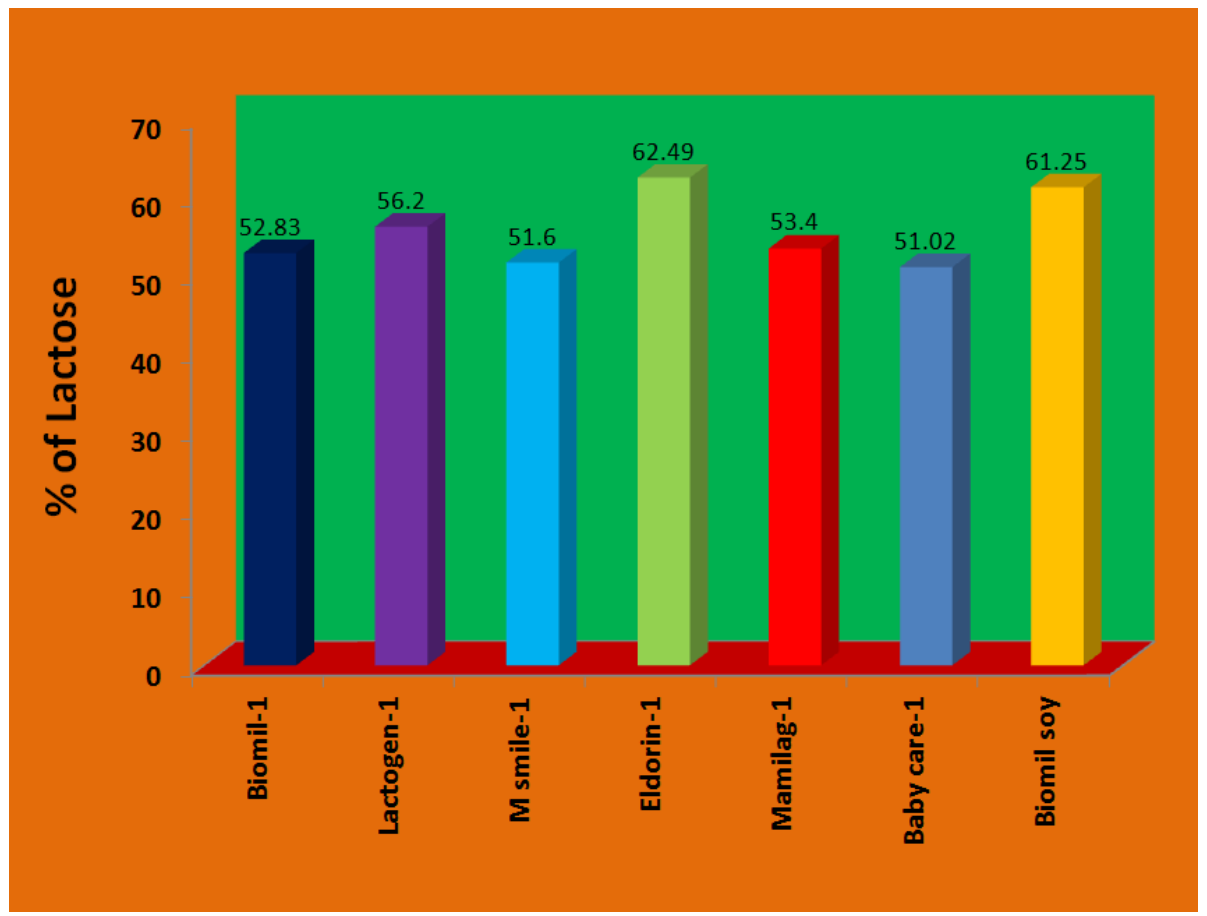

Fig. 2. The variation of percentage of lactose in baby (0-6 months) powdered milk of different brands. 
Lactose found in mother milk is $7.0 \mathrm{~g} / 100 \mathrm{ml}$ (Constituents of human milk, United Nations University Centre).

The acidity of baby ( 0 to 6 months) powdered milk ranges from $0.66 \%$ to $1.28 \%$. Biomil soy has the highest acidity
$(1.28 \%)$ and Lactogen- 1 has the lowest acidity $(0.66 \%)$. The acidity of powdered milk meets the requirement of the standards of USA which is less than $1.5 \%$ [13].

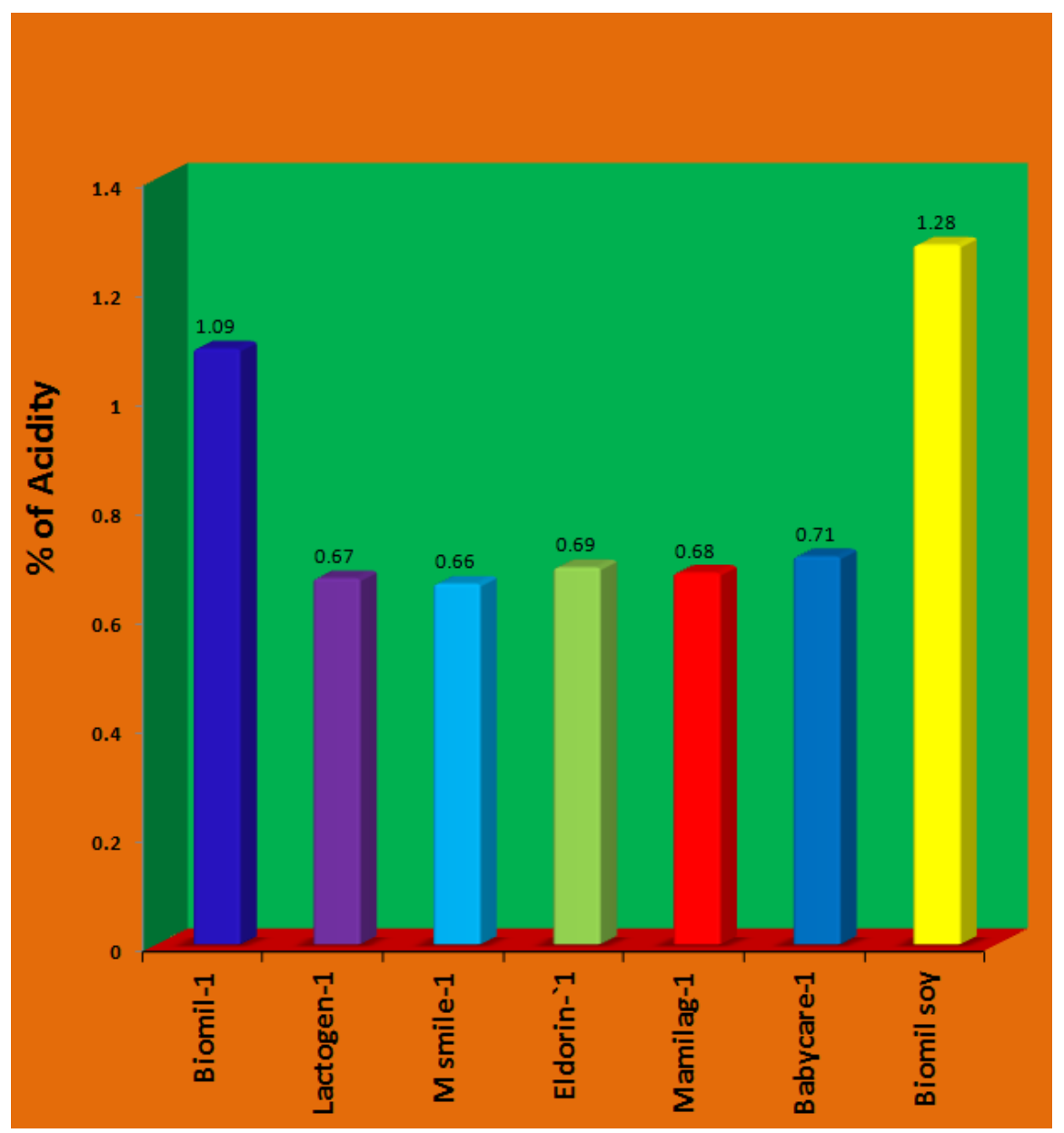

Fig. 3. The variation of percentage of acidity in baby (0-6 months) powdered milk of different brands.

From the table 1, it is seen that 107.69, 109.28, 108.90, 108.40, 109.28, 108.30 and 110.69 gram powder Biomil-1, Lactogen-1, Mother's smile-1, Eldorin-1, Mamilag-1, Baby care-1 and Biomil soy required respectively to prepare per liter of milk equivalent to that amount of breast milk. A survey goes that on an average an infant can take $500 \mathrm{ml}$ breast milk per day. Now if an infant is given the same amount of powder milk instead of mother milk per day it is seen that the infant consumes 53.85, 54.64, 54.45, 54.20, $54.64,54.15$ and 55.80 gram powder of Biomil-1, Lactogen1, Mother's smile-1, Eldorin-1, Mamilag-1, Baby care-1 and Biomil soy respectively per day. The daily intake of protein and lactose by infants from baby (0-6 months) powdered milk are shown in the table 2.

From the table 2 it is found that the highest amount of protein is present in Biomil soy $(9.52 \mathrm{~g})$ and the lowest amount of protein is present in Lactogen-1 (8.14 g). The amount of protein present in mother milk is $1.13 \mathrm{~g} / 100 \mathrm{ml}$ or $5.65 \mathrm{~g} / 500 \mathrm{ml}$. The daily intake of protein is $9.1 \mathrm{~g}$. It is seen that studied samples contain amount of protein close to the daily intake of protein. It shows that studied samples are free from protein deficiency and excessive intake of protein.

Table 2. Amount of Protein and Lactose from baby powdered milk consumed by infants per day.

\begin{tabular}{llll}
\hline Name of brands & Country of origin & $\begin{array}{l}\text { Protein } \\
\text { (g/day) }\end{array}$ & $\begin{array}{l}\text { Lactose } \\
\text { (g/day) }\end{array}$ \\
\hline Biomil-1 & Belgium & 8.37 & 26.66 \\
Lactogen-1 & Switzerland & 8.14 & 27.92 \\
Mother's smile-1 & Australia & 8.53 & 26.19 \\
Eldorin-1 & Netherland & 8.38 & 30.75 \\
Mamilag-1 & Poland & 8.28 & 26.80 \\
Baby care-1 & Korea & 8.37 & 25.01 \\
Biomil soy & Belgium & 9.52 & 30.31 \\
\hline
\end{tabular}

The amount of lactose present in baby powdered milk ranges from $25.01 \mathrm{~g}$ to $30.75 \mathrm{~g}$. The highest amount of lactose is found in Eldorin-1 (30.75 g) and the lowest amount of lactose is found in Baby care-1 (25.01 g). The amount of lactose present in mother milk is $7.0 \mathrm{~g} / 100 \mathrm{ml}$. or 35.0 $\mathrm{g} / 500 \mathrm{ml}$. From the table 2 it shows that Eldorin-1 and Biomil soy contains lactose close to mother milk. 
From the table 2 it is found that the highest amount of protein is present in Biomil soy $(9.52 \mathrm{~g})$ and the lowest amount of protein is present in Lactogen-1 $(8.14 \mathrm{~g})$. The amount of protein present in mother milk is $1.13 \mathrm{~g} / 100 \mathrm{ml}$ or $5.65 \mathrm{~g} / 500 \mathrm{ml}$. The daily intake of protein is $9.1 \mathrm{~g}$. It is seen that studied samples contain amount of protein close to the daily intake of protein. It shows that studied samples are free from protein deficiency and excessive intake of protein.

The data on the far left of the table 1 give idea about the amount of powdered milk of each brand to prepare one liter equivalent milk that is equivalent to mother milk. A variation is observed in the amount of different brands powdered milk to prepare equivalent milk. It is seen that $111.60 \mathrm{~g}$ powder of Biomil soy brand is necessary to make one liter equivalent milk whereas only $107.69 \mathrm{~g}$ of Biomil-1 brand is needed for the same purpose. This information will help the user to select the economic brand and also to know how much powdered milk of each brand required preparing equivalent milk. From this view Biomil-1 is more economical than any other brands.

\section{Conclusion}

The study aimed to test for the presence of important biochemical parameters, such as percentage of protein, lactose and acidity of the studied milk samples. Fourteen types of infant formula milk and ten types of baby cereal were subjected to testing and results were collected.

In view of the experimental results of the biochemical analysis of different milks, it could be concluded that the investigated milk showed good result with few exceptions. Protein in all these milks may be due to the presence of nonprotein nitrogenous substances such as urea nitrogen amino nitrogen, creatinine, uric acid, adenine and guanine.

The percentage of lactose in baby powdered milk of 0-6 months varies from 50 to $61 \%$ and 51 to $59 \%$ in 6-24 months baby powdered milk. The lactose is found in some samples exceed their given value and some of them contain comparatively lesser amount of lactose than their given value. The decreased value indicates that some lactose may be lost during processing of the raw milk or other carbohydrate such as sucrose (non-reducing) may be added which give the total carbohydrate value higher. The reason for decreases of the lactose content may be due to either decomposition of lactose during processing of milk or some conversion of lactose to lactic acid by bacteria.
The information gained from these measurements will provide a baseline level of toxicity for baby powdered milks. This research will also help consumers, manufacturers and professionals to realize about the possible direct or cumulative effects of the health care system.

\section{References}

[1] World Health Organization (WHO), 2003.

[2] Rodriguez EM, Sanz AM, Díaz RC (2000) Concentrations of iron, copper and zinc in human milk and powdered infant formula. Int J Food Sci Nutr 51(5):373-380

[3] World Health Organization/Food and Agriculture Organization of the United Nations (2008) CAC/RCP 66-2008 - Code of Hygienic Practice Powdered Formulae for Infants and Young Children, Codex Alimentarius Commission, 1-29

[4] Lönnerdal B, Kelleher SL (2009) Micronutrient transfer: infant absorption. Adv Exp Med Biol 639:29-40.

[5] Renfrew MJ, Pokhrei S, Quigley M, et al (2012). Preventing Disease and Saving Resources: The Potential Contribution of Breastfeeding Rates in the UK. London: UNICEF

[6] Crampton, E. E.; Harris, L .E. Applied Animal Nutrition, $2^{\text {nd }}$ Ed.; Freeman and Co.: San Francisco, 1969, p 50-53.

[7] AOAC. Official Methods of Analysis. 15 $5^{\text {th }}$ ed., Association of Official Analytical Chemists, Arlington, VA, 1990.

[8] Heinemann, P.G. Milk, W.B. Saunders Company, Philadelphia and London, 1919, p 195.

[9] James, C. S., Analytical chemistry of food. Seale- Heany Faculty of Agriculture, Food and Land use, Department of Agriculture and Food studies, University of Plymouth, UK, 1 (1995) $96-97$

[10] Heineman, P. G. Milk, W. B. Saunders Company, Philadelphia and London, 1919, p. 195.

[11] Lampert, L. M. Milk and Dairy Products, Their Composition, Food Value, Chemistry, Bacteriology and Processing, Chemical Publishing Co.; Inc., Broklyn, NY, 1947, p. 242.

[12] Eckles, C. H.; Combs, W. B.; Macy, H. Milk and Milk Products, $4^{\text {th }}$ ed.; Tata McGraw-Hill Publishing Company Ltd.: New Delhi, 1973.

[13] Dr. K.C. Chaudhuri. Protein content of breast milk of Indian mothers with malnourished children. Indian journal of pediatrics. 2008 . 